I am grateful to Dr. W. P. Rogers, under whose direction this work was carried out, and to Dr. L. G. Goodwin, of the Wellcome Laboratories, who supplied the strain of $P$. berghei used in these experiments. P. R. WHITFELD

Division of Animal Health and Production, (an McMaster Scholar) Commonwealth Scientific and Industrial Research Organization, McMaster Laboratory, Sydney. Oct. 15.

${ }^{1}$ Caspersson, T. O., Symp. Soc. Exp. Biol., 1, 127 (1947).

"Caspersson, T. O., "Cell Growth and Cell Function" (Norton and Co., Inc., New York, 1950).

- Schneider, W. C., J. Biol. Chem., 161, 293 (1945).

- Vendrely, R., and Vendrely, C., Experientia, 4, 434 (1948).

- Davidson, J. N., and McIndoe, W. M., Biochem. J., 45, xvi (1949).

- Moses, M. J., J. Morph., 87, 493 (1950).

7 Davidson, J. N., and Waymouth, C., Biochem. J., 38, 379 (1944).

- Marshak, A., and Vogel, H. J,, J. Biol. Chem., 189, 597 (1951).

- Wyatt, G. R., Biochem. J., 48, 584 (1951).

\section{Occurrence of Larval Helminths in Gammarus pulex (L.) from the Braid Burn, Edinburgh}

IN the course of investigations on larval helminths while working in the University of Edinburgh, I found that Gammarus pulex (L.), which occurred abundantly throughout the year in the Braid Burn, near the Department of Zoology, harboured larval helminths of five different kinds-two species of Acanthocephala, Polymorphus minutus (Goeze) and Echinorhynchus truttce Schrank, two species of cysticercoids new to science, and one form of plagiorchid metacercaria. So far as I am aware, this is the first record of a larval cestode infection in Gammarus pulex (L.) in Great Britain.

The two forms of cysticercoids occurred separately and were found attached to the connective tissue of the outer wall of the intestine of the amphipod. One of these, named Cysticercoid braidburni n.sp. (Figs. 1 and 2), bears on its rostellum 55-59 bifid hooks which measure approximately $0.01 \mathrm{~mm}$. long. The cysts are oval to elliptical and measure $0.23-0.28$ $\mathrm{mm} . \times 0.16-0.175 \mathrm{~mm}$. The four rostellar suckers are devoid of spines. This cysticercoid is closely allied to Cysticercus integrus Hamann, 1890, but differs from it in possessing a body half the size, and in having much smaller and fewer hooks of different shape. The other cysticercoid obtained from Gammarus pulex (L.), which is named Cysticercoid gammari n.sp. (Figs. 3 and 4), has on its rostellum only 10 hooks measuring $0.025-0.027 \mathrm{~mm} . \times 0.0038$ mm., and its four rostellar suckers are also devoid of spines. The cysts are almost spherical, $0.31 \mathrm{~mm}$. $\times 0.33 \mathrm{~mm}$. in size. Of the known ten hooked cysticercoids, the present form comes nearest, in general characters, to Cysticercus echinocotyle and Cysticercus
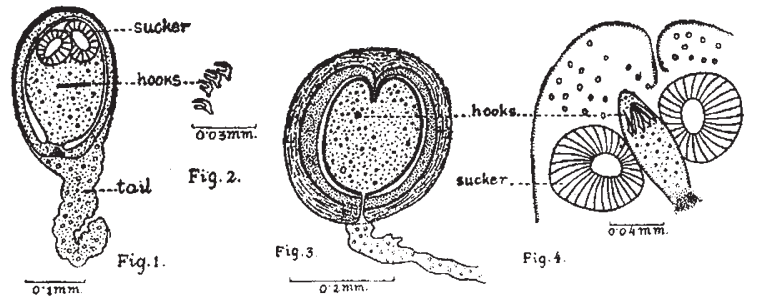

' $B$ ' Harper, from both of which it differs, apart from other characters, in lacking spines on its suckers, and to Cysticercus tenuirostris, Cysticercus mirabilis and Cysticercus fimbriarioe, from each of which it differs, besides other characters, in having hooks of different size and shape.

I take this opportunity to thank Prof. James Ritchie, of the University of Edinburgh, who afforded me facilities for carrying out this investigation in the Department of Zoology there.

Department of Zoology,

University, Lucknow.

Sept. 10.

\section{Staurophora mertensii Brandt in the Firth of Clyde}

IT may be of interest to record the occurrence of considerable numbers of the arctic Leptomedusan, Staurophora mertensii Brandt ${ }^{1}$, in the Firth of Clyde during the summer of 1951. Only two specimens have actually been examined; but reports were received on several "occasions of medusæ described as having cruciform gonads of dark brown or black colour and 5-6 cm. in diameter when first seen at the end of May, increasing later to more than $15 \mathrm{~cm}$. Since no other medusa with cruciform gonads exceeds about $5 \mathrm{~cm}$. in diameter, there can be little doubt that these medusæ were Staurophora. From these reports it appears to have been common in the water around Bute and the Cumbraes from May to July; but it may have been more widely distributed, since one of the specimens examined was taken on May 30 ten miles south of Ailsa Craig, that is, nearly fortyfive miles south of Millport.

In the Atlantic, Staurophora is found off the American coast north of Cape Cod and the coasts of Greenland, in the waters around Iceland and the Faroes, and off the Norwegian coast north of Bergen ${ }^{1}$. It is found occasionally around the Shetlands and, although sporadic irruptions into the northern North Sea have been recorded ${ }^{1-3}$, this is believed to be the first time that it has been reported on the west coast of Scotland. Staurophora does not normally occur in the warm water west of the Hebrides, and in 1951 the only records obtained by the Scottish fisheries research vessels were from west of the Faroes in August and late September.

It is difficult to account for this exceptional occurrence of Staurophora; the nearest known endemic population, that around the Faroes, is about 400 miles to the north, and the Firth of Clyde is open only to the south-west. It is possible, however, that the medusæ seen in 1951 were released by hydroids which had been brought into the Firth of Clyde from either arctic or Canadian waters as fouling on the bottom of a ship.

I should like to thank Mr. F. S. Russell for confirming my identification of the medusa, and Dr. J. H. Fraser for supplying information about its distribution in the Faroe and Shetland areas.

$$
\text { D. T. Gavld }
$$

The Marine Station, Millport. Dec. 10.

Kramp, P. I.., "Nordisches Plankton", 12, 559 (1933).

'Kramp, P. I., K. danske Vidensk. Selsk. Skr. Naturvid. og Math., Afa, 8, Raekke 12 (1927).

${ }^{3}$ Russell, F. S., J. Mar. Biol. Assoc., 24, 515 (1940).

- Fraser, J. H. (personal communication). 